\title{
Enhancing The Ic Engine Performance By Using The Electrolysis And Preheating Process
}

\author{
Dr.R.Sudhakaran ${ }^{1}$,G.Aravinthkumar ${ }^{2}$, \\ M.Naveenkumar ${ }^{3}$, S.Veerakumar ${ }^{4}$, M.Vigneshvar ${ }^{5}$ \\ ${ }^{1}$ Head, Department of Mechanical Engineering, SNS College of Engineering, Coimbatore, India \\ 2.3, 4,5 Student,Department of Mechanical Engineering, SNS College of Engineering, Coimbatore, India
}

\begin{abstract}
Our present fuel resources are not going to be around forever and with the ever increasing consumption their extinction is nearly unavoidable. Also our fuel resources which are mostly made up of fossil fuels are not renewable in nature. Currently around the world the consumption of fossil fuels is 100,000 times faster than their natural production. According to an estimate the demand for these fuels will suddenly outstrip their availability in a matter of centuries-or less. Also the combustion of fossil fuels emits carbon dioxide. This harmful gas when released into the atmosphere makes a huge contribution to the greenhouse effect. This effect prompts the atmosphere to capture and reflect back the energy that radiate from the surface of the earth, instead of letting them to escape back into space. This causes global warming that melts the polar ice caps and affects weather all around the world. This project is discusses about the variability of using $\mathrm{H}_{2}$ as a fuel along with petroleum. There are many reasons to choose $\mathrm{H}_{2}$ as a motive power. $\mathrm{H}_{2}$ has one of the highest gravimetric energy densities of all available fuels, which means it has very high energy content per unit mass $(143 \mathrm{MJ} / \mathrm{kg})$ $40 \%$ more than other. Also we have to preheat the inlet air to get the more efficient for the performance of engine.
\end{abstract}

Index Terms- four stroke petrol engine, hydrogen gas, air preheater, fuel consumption, emission control.

\section{Introduction}

The burning of fossil fuels is warming the planet, melting glaciers and polar ice caps, raising sea levels, causing more destructive hurricanes, floods, and droughts, and increasing ocean acidity. Leading climate experts hold that a third of existing petroleum reserves will add enough carbon dioxide to push the planet past the tipping point of irreversible climate change.As per the International Energy Agency's "business-as-usual" forecast, even if oil production peaks in 2010 and immediately starts to fall at 3\% a year, the total emissions would rise by $25 \%$, reaching 32 billion tons in 2030 . We need to be well on the way to at least a $60 \%$ cut in emissions. So it is quite possible to run out of oil and pollute the planet to destruction simultaneously.

After various researches the petrol engine is modified by various process like Turbo charging, Supercharging, Alternative fuels, Fuel ignition and Modification in design of engine parts to increase the efficiency of engine and to control pollution. It is very important to note that there is no modification made in inlet atmospheric air and mixing the air with hydrogen gas for efficient burning.This project is based on the above statement of increasing the IC engine performance by adding hydrogen gas to the preheated atmospheric air for better burning of gas and to increase efficiency and to control pollution.

\section{Electrolysis Process 1.1 Definition}

Electrolysis of water is the decomposition of water $\left(\mathrm{H}_{2} \mathrm{O}\right)$ into oxygen $\left(\mathrm{O}_{2}\right)$ and hydrogen gas $\left(\mathrm{H}_{2}\right)$ due to an electric current being passed through the cathode and anode into water.

\subsection{Working Principle}

An electrical power source is connected to two electrodes, or two plates (typically made from some inert metal such as platinum, stainless steel or iridium) which are placed in the water. Hydrogen will appear at the cathode (the negatively charged electrode, where electrons enter the water), and oxygen will appear at the anode (the positively charged electrode). Assuming ideal faradaic efficiency, the amount of hydrogen generated is twice the number of moles of oxygen, and both are proportional to the total electrical charge conducted by the solution. However, in many cells competing side reactions dominate, resulting in different products and less than ideal faradaic efficiency. 


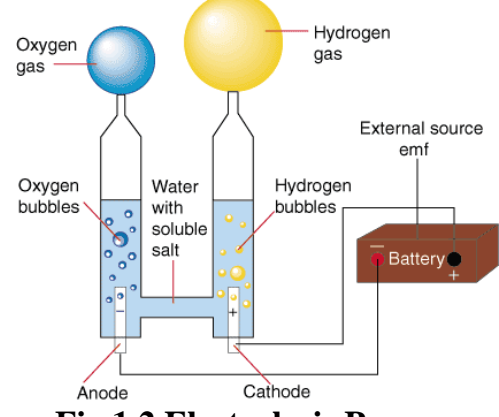

Fig 1.2 Electrolysis Process

\subsection{Air Preheater}

\section{Preheating Process}

An air preheater (APH) is a general term to describe any device designed to heat air before another process (for example, combustion in a boiler) with the primary objective of increasing the thermal efficiency of the process.

The concept of increasing the fuel efficiency of a petrol engine is to pre-heat the intake air which is flowing through the carburetor. The humidity in the atmospheric air affects the petrol vaporization in the carburetor. Therefore, by pre-heating the inlet air to the carburetor for a considerable amount, the vaporization can be ease and in turn complete combustion is achieved. Moreover by reducing the water vapour to the engine, the steam formation in the engine can be reduced pitting of the engine cylinder, piston and exhaust pipe.The first problem is selecting suitable materials to serve the design purpose. The material should also be locally available. It should be best studied and also cheap in cost. Baffle plates and tubes should have very good thermal conductivity. It should also be resistant to chemical corrosion as well as erosion. In order to fulfill the above considerations, aluminum is taken as a preheater.

\subsection{Preheater Setup in Two Wheelers}

The pre-heating of inlet air to the engine can be achieved by fixing a heat exchanger inside the exhaust pipe. The atmospheric air is sucked through the heat exchanger to the carburetor. The air which is flowing though the heat exchanger gets heated by the engine exhaust gas. This reduces the water vapour in the inlet air and the temperature of the air is raised. The temperature raise causes complete combustion in the engine and it is also more suitable for warming up the engine in cold conditions.

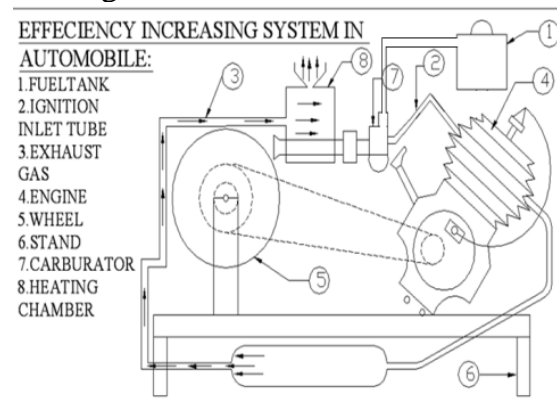

Fig 2.2 Layout of preheater setup

\section{Experimental Setup}

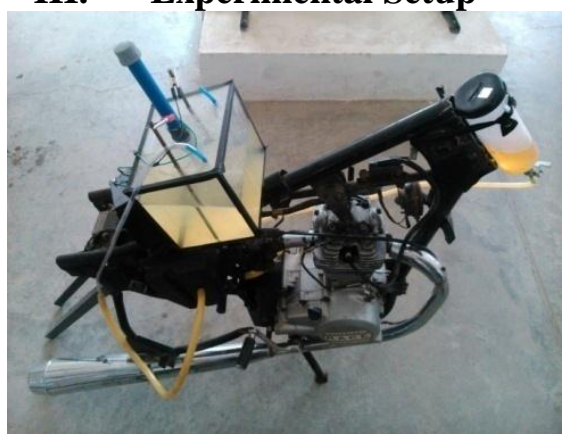




\section{Working Principle}

Check the connections are given as per the line diagram.

Switch on the key, which makes the battery ON to activate the electrolysis kit.

\subsection{Suction Stroke}

When the piston moves from TDC to BDC, (i.e., suction stroke) Vacuum is created which opens the intake valve. Due to the creation of vacuum, air is drawn from atmosphere and hydrogen gas from the electrolysis kit. Both the air and gas passes to the pre-heater, which is preheated and increases temperature by the external flow of exhaust gases. Now, the pre-heated air and $\mathrm{H} 2$ gas is passes to the carburetor in which the air+H2gas+petrol gets mixed in required proportions. Then the mixture is drawn into the cylinder up to the piston reaches BDC. At the end of suction stroke the inlet valve gets closed.

\subsection{Compression Stroke}

Now the piston moves from BDC to TDC, in which the air and hydrogen gas and the petrol mixture get compressed, which results in increase in temperature. At the end of compression stroke the piston reaches TDC at the time Power stroke will starts by igniting the mixture through spark plug.During this stroke both the valves are in closed condition.

\subsection{Power Stroke}

Thus the ignited mixture produces high power which pushes the piston downwards at high pressure from TDC to BDC. During this period the mixture gets burned completely as much as higher compared to other 4stroke Petrol engines due to, "Pre-heated air and Hydrogen gas". Then the power obtained in the cylinder is transmitted to drive wheel through connecting rod, crankshaft and flywheel. Thus there is no timing delay in burning of mixture which results in decreasing of "Knocking".

\subsection{Exhaust Stroke}

During this stroke the piston moves from BDC to TDC by opening the exhaust valve. The upward movement of this stroke blows out the burned gases outside the cylinder. When the piston reaches TDC exhaust valve closes and inlet valve gets opened and suction stroke starts. Then this operation continues...

\section{Practical Observation}

The road test was conducted using $50 \mathrm{ml}$ of fuel and its observation are as follows in two different conditions

\begin{tabular}{|c|c|c|c|c|c|}
\hline \multicolumn{6}{|c|}{ Fuel Only } \\
\hline \multirow{2}{*}{$\begin{array}{l}\text { S.N } \\
\text { O }\end{array}$} & \multirow{2}{*}{$\begin{array}{l}\text { FUEL } \\
\text { USED } \\
\text { (ml) }\end{array}$} & \multirow{2}{*}{$\begin{array}{l}\text { SPEED } \\
\text { IN (rpm) }\end{array}$} & \multicolumn{2}{|c|}{$\begin{array}{l}\text { ODOMETER } \\
\text { READING (km) }\end{array}$} & \multirow{2}{*}{$\begin{array}{l}\text { DISTANCE } \\
\text { COVERED IN } \\
(\mathbf{k m})\end{array}$} \\
\hline & & & $\begin{array}{l}\text { INTIA } \\
\mathrm{L}\end{array}$ & FINAL & \\
\hline 1 & 50 & $0-40$ & 2 & 3.8 & 1.8 \\
\hline 2 & 50 & $0-40$ & 4 & 5.7 & 1.7 \\
\hline 3 & 50 & $0-40$ & 6 & 7.8 & 1.8 \\
\hline 4 & 50 & $0-40$ & 8 & 9.9 & 1.9 \\
\hline
\end{tabular}

Fuel With Hydrogen

\begin{tabular}{|c|c|c|c|c|c|}
\hline \multirow{2}{*}{$\begin{array}{l}\text { S.N } \\
\text { O }\end{array}$} & \multirow{2}{*}{$\begin{array}{l}\text { FUEL } \\
\text { USED } \\
(\mathrm{ml})\end{array}$} & \multirow{2}{*}{$\begin{array}{l}\text { SPEED } \\
\text { IN (rpm) }\end{array}$} & \multicolumn{2}{|c|}{$\begin{array}{l}\text { ODOMETER } \\
\text { READING }(\mathbf{k m})\end{array}$} & \multirow{2}{*}{$\begin{array}{l}\text { DISTANCE } \\
\text { COVERED IN } \\
(\mathrm{km})\end{array}$} \\
\hline & & & $\begin{array}{l}\text { INTIA } \\
\text { L }\end{array}$ & FINAL & \\
\hline 1 & 50 & $0-40$ & 10 & 12.3 & 2.3 \\
\hline 2 & 50 & $0-40$ & 13 & 15.3 & 2.3 \\
\hline 3 & 50 & $0-40$ & 16 & 17.4 & 2.4 \\
\hline 4 & 50 & $0-40$ & 18 & 19.3 & 2.3 \\
\hline
\end{tabular}

AVERAGE $=2.3$

\subsection{Technical Specification}

\section{Laboratory Test}

$$
\begin{array}{ll}
\text { Drum radius } & =58 \mathrm{~mm} \\
\text { Belt radius } & =3 \mathrm{~mm} \\
\text { Fuel } & =\text { Petrol }
\end{array}
$$


Enhancing The Ic Engine Performance By Using The Electrolysis And Preheating Process

6.2 Load test on 4-stroke petrol engine before installing the $\mathrm{H}_{2} \mathrm{O}$ kit

\begin{tabular}{|c|c|c|c|c|c|c|c|c|c|c|c|}
\hline $\begin{array}{l}\text { S.N } \\
\text { O }\end{array}$ & $\begin{array}{l}\text { Load(W) } \\
\text { in } \\
\mathrm{kg} \\
\mathrm{W} 1-\mathrm{W} 2\end{array}$ & $\begin{array}{l}\text { Speed } \\
(\mathrm{N}) \\
\text { rpm }\end{array}$ & $\begin{array}{l}\text { Time for } \\
10 \mathrm{cc} \\
\text { fuel } \\
\text { consumption }\end{array}$ & $\begin{array}{l}\mathrm{TFC} \\
\mathrm{Kg} / \mathrm{h} \\
\mathrm{r}\end{array}$ & $\begin{array}{l}\mathrm{BP} \\
\text { in } \\
\mathrm{KW}\end{array}$ & $\begin{array}{l}\text { FP } \\
\text { in } \\
\mathrm{KW}\end{array}$ & $\begin{array}{l}\mathrm{IP} \\
\text { in } \\
\mathrm{KW}\end{array}$ & $\begin{array}{l}\mathrm{SFC}=\mathrm{TFC} / \\
\mathrm{BP} \mathrm{kg} / \mathrm{KW}- \\
\mathrm{hr}\end{array}$ & $\eta_{\text {mech }}$ & $\eta_{\text {overall }}$ & $\eta_{\text {thermal }}$ \\
\hline 1 & 2 & 2946 & 32 & 0.88 & 0.83 & 0.12 & 0.96 & 1.06 & 86.4 & 8.2 & 9.6 \\
\hline 2 & 4 & 2919 & 32.67 & 0.86 & 1.65 & 0.24 & 1.89 & 0.52 & 87 & 16.83 & 19.3 \\
\hline 3 & 6 & 2890 & 33.78 & 0.83 & 2.42 & 0.36 & 2.78 & 0.34 & 87 & 26.5 & 29.6 \\
\hline 4 & 8 & 2868 & 34.8 & 0.80 & 3.2 & 0.48 & 3.68 & 0.25 & 87 & 34.82 & 40 \\
\hline 5 & 10 & 2844 & 36.2 & 0.78 & 3.96 & 0.59 & 4.56 & 0.20 & 87 & 45 & 51.6 \\
\hline
\end{tabular}

6.3 Load test on 4-stroke petrol engine after installing the $\mathrm{H}_{2} \mathrm{O}$ kit

\begin{tabular}{|l|l|l|l|l|l|l|l|l|l|l|l|}
\hline $\begin{array}{l}\text { S.N } \\
\text { O }\end{array}$ & $\begin{array}{l}\text { Load(W) } \\
\text { in } \\
\text { kg } \\
\text { W1-W2 }\end{array}$ & $\begin{array}{l}\text { Speed } \\
\text { (N) } \\
\text { rpm }\end{array}$ & $\begin{array}{l}\text { Time for } \\
10 \mathrm{cc} \\
\text { fuel } \\
\text { consumption }\end{array}$ & $\begin{array}{l}\text { TFC } \\
\text { Kg/hr }\end{array}$ & $\begin{array}{l}\text { BP } \\
\text { in } \\
\text { KW }\end{array}$ & $\begin{array}{l}\text { FP } \\
\text { in } \\
\text { KW }\end{array}$ & $\begin{array}{l}\text { IP } \\
\text { in } \\
\text { KW }\end{array}$ & $\begin{array}{l}\text { SFC=TFC/ } \\
\text { BP kg/KW- } \\
\text { hr }\end{array}$ & $\eta_{\text {mech }}$ & $\eta_{\text {overall }}$ \\
\hline 1 & 2 & 2984 & 34 & 0.83 & 0.83 & 0.12 & 0.96 & 1 & 86.4 & 9 & 10.2 \\
\hline 2 & 4 & 2934 & 24.5 & 0.81 & 1.67 & 0.25 & 1.92 & 0.48 & 86.9 & 18 & 20.7 \\
\hline 3 & 6 & 2898 & 34.92 & 0.8 & 2.43 & 0.36 & 2.8 & 0.33 & 87 & 26.5 & 30.5 \\
\hline 4 & 8 & 2886 & 35.2 & 0.79 & 3.22 & 0.48 & 3.7 & 0.24 & 87 & 35.4 & 41 \\
\hline 5 & 10 & 2852 & 37.12 & 0.75 & 4.02 & 0.60 & 4.62 & 0.18 & 86.9 & 47 & 53.7 \\
\hline
\end{tabular}

VII. Result Analysis

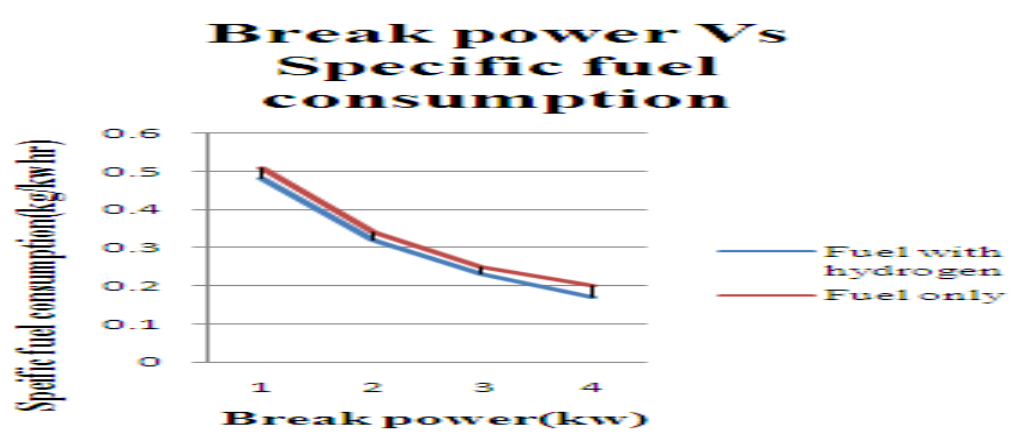

Brealz power vs

Thermal
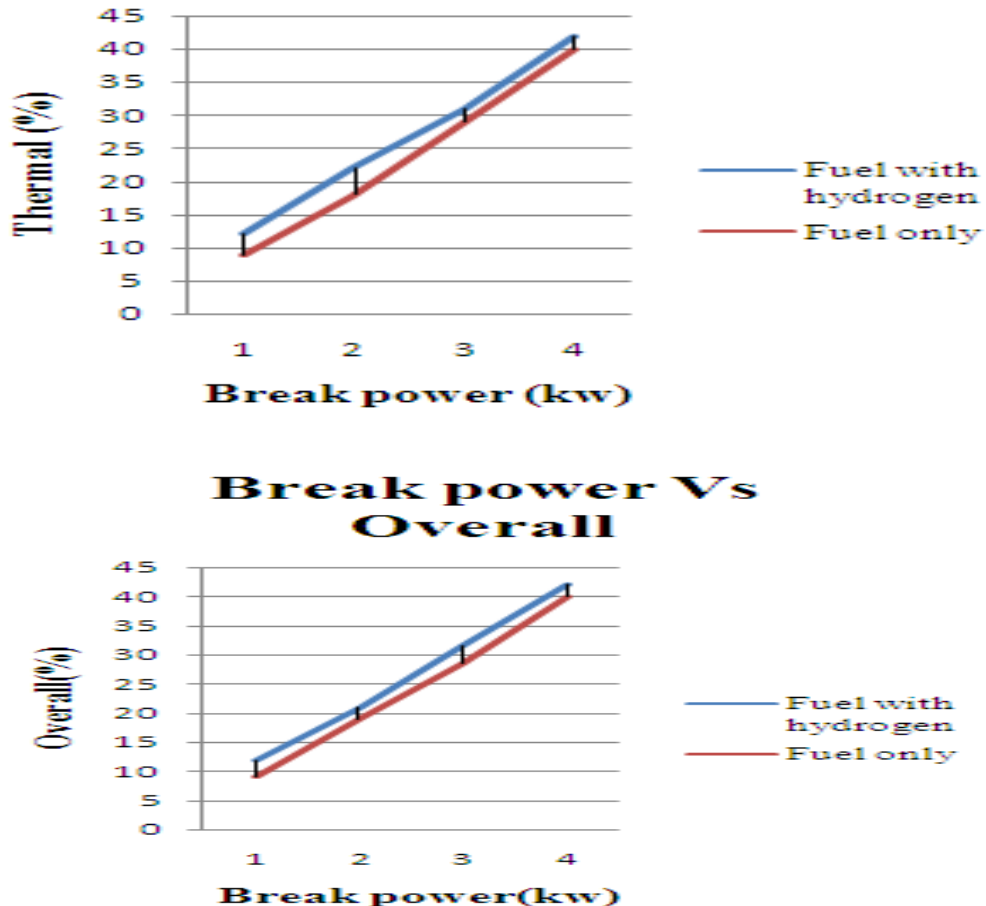


\section{Conclusion}

From the investigation it has been informed that the efficiency of single cylinder four stroke petrol engines is increased by $2-3 \%$ using the hydrogen gas along with the petroleum. Hence SFC is decreased by $0.03 \mathrm{~kg} / \mathrm{kw}$-hr. Here is a reduction in fuel consumption. Hence there is an potential to use hydrogen gas as a motive power in petrol engines which results in conservation of energy.

\section{Acknowledgement}

I am deeply indebted and grateful to my project guide, DR.R.SUDHAKARAN Head of the Department, Mechanical Engineering Department, SNS College of Engineering, for his valuable suggestions, encouragement and effective guidance. I also extend my thanks to Teaching and Non-teaching staffs of mechanical engineering department who have helped me in carrying out this project successfully.

\section{References}

[1]. Kreuter W, and Hofmann H, 1998, Electrolysis: the important energy transformer in a world of sustainable energy, Int. J. Hydrogen Energy 23(8): 661-666.

[2]. Neagu C, Jansen H, Gardeniers H, and Elwenspoek M, 2000, The electrolysis of water: An actuation principle for MEMS with a big opportunity, Mechatronics: 571-581

[3]. Heywood, J. B. (1988). Internal combustion engine fundamentals. New York: McGraw-Hill, ISBN 0-07-100499- 8.

[4]. Hires, S. D., Tabaczynski, R. J., \& Novak, J. M. (1978). The prediction of ignition delay and combustion intervals for a homogeneous charge, spark ignition engine. SAE Transactions 87, SAE Technical Paper780232.

[5]. Automobile Engineering - Tech India Publication Series - R.B. GUPTA

[6]. Internal Combustion Engines - Tata McGraw-Hill Publishing Company Limited - Second Edition - V. GANESAN. 